\title{
PENGEMBANGAN PERANGKAT PEMBELAJARAN INKUIRI BERBANTUAN PROGRAM SIMULASI PhET UNTUK MELATIHKAN KETERAMPILAN PROSES DAN PEMAHAMAN KONSEP IPA
}

\author{
Mohammad Azis ${ }^{1)}$ \\ Leny Yuanita ${ }^{2}$ \\ Yuni Sri Rahayu ${ }^{3)}$ \\ ${ }^{1)}$ Mahasiswa Prodi Pendidikan Sains Pascasarjana Universitas Negeri Surabaya \\ ${ }^{2)}$ Dosen Prodi Pendidikan Sains Program Pascasarjana Universitas Negeri Surabaya \\ ${ }^{3)}$ Dosen Prodi Pendidikan Sains Program Pascasarjana Universitas Negeri Surabaya \\ e-mail: kangdaengnaba@gmail.com
}

\begin{abstract}
Abstrak: Penelitian ini bertujuan mengembangkan perangkat pembelajaran inkuiri berbantuan program simulasi PhET untuk melatihkan keterampilan proses sains dan pemahaman konsep IPA pada materi asam, basa dan garam di kelas VII SMP Negeri 3 Sugio Lamongan. Pengembangan perangkat pembelajaran dalam penelitian ini dilaksanakan dengan menggunakan Model 4-D dari Thiagarajan, yang terdiri dari tahap-tahap pengembangan, yaitu: define, design, develop, tanpa menggunakan tahap disseminate. Hasil penelitian menunjukkan: (1) validitas isi Rencana Pelaksanaan Pembelajaran, Buku Ajar Siswa, Lembar Kegiatan Siswa, instrumen tes pemahaman konsep, dan instrumen tes keterampilan proses berkategori baik dan layak digunakan; tingkat keterbacaan Buku Ajar Siswa dan Lembar Kegiatan Siswa tinggi dan mudah dipahami, (2) keterlaksanaan Rencana Pelaksanaan Pembelajaran sangat baik, aktivitas siswa dalam pembelajaran baik, dan respon siswa terhadap perangkat yang dikembangkan dan pembelajaran yang dilakukan sangat baik, dan (3) keefektifan perangkat pembelajaran sangat baik, yang diindikasikan dengan dicapainya ketuntasan hasil belajar keterampilan proses sains dan pemahaman konsep IPA. Berdasarkan temuan penelitian, disimpulkan bahwa perangkat pembelajaran inkuiri berbantuan program simulasi PhET memiliki kelayakan, kepraktisan dan keefektifan yang baik sehingga dapat diterapkan dalam kegiatan pembelajaran di SMP kelas VII.
\end{abstract}

Kata-kata Kunci: Keterampilan Proses, Pemahaman Konsep, Inkuiri, dan PhET.

\begin{abstract}
This researchaims todevelopinquiry learningmaterials using PhET simulationprogramto facilitatescience process skillsandscienceconceptsunderstanding in the junior grade VIIinSMPNegeri 3SugioLamongan.The development oflearningmaterialsin the researchcarried out using4-D modelofThiagarajan, whichconsistsofstagesof development,namely: define, design, develop, without usingdisseminatestage. The results were obtained:(1) the validity ofthe content ofthe lesson plan, textbook, worksheets, concepts comprehensiontest instrument, and processskillstest instrumentcategorizedwellandfit for use, readability of textbookandworksheets have high level/easy to understand, (2) adherence to thelesson planis very good, students activity is goodin learning, and thestudents' response tothe learningmaterialss developedandperformedverywell, and (3) the effectiveness ofthe learningmaterialssogood, thatindicatedbymasteryof learningoutcomesof science process skillsandscienceconceptsunderstanding are exceeded. Based on the research results, it can be concludedthattheinquiry learningmaterials with PhETsimulationprogramhasfeasibility, enforceabilityandeffectiveness ofthe good category thatcan be appliedinlearning activitiesingrade VII of SMP.
\end{abstract}

Keywords: Skills of Process, Understanding ofConcepts, Inquiry, and PhET

\section{PENDAHULUAN}

Berbagai inovasi di bidang pendidikan yang dilakukan selama ini ditujukan untuk meningkatkan kualitas pendidikan secara menyeluruh. Dalam konteks pembelajaran, peningkatan kualitas ini ditunjukkan dalam bentuk penguasaan kompetensi tertentu sebagai target dan indikator keberhasilan belajar siswa pada satuan pendidikan. Hal ini sejalan dengan desain kurikulum yang saat ini digunakan, yaitu kurikulum yang bercirikan: (1) penekanan pada pencapaian kompetensi siswa baik secara individual maupun klasikal, (2) berorientasi pada hasil (learning outcomes) dan keberagaman, (3) proses pembelajaran menggunakan pendekatan dan metode yang bervariasi, (4) sumber belajar tidak terbatas pada guru tetapi dapat dilengkapi dengan berbagai sumber lain yang relevan, dan (5) penilaian lebih ditekankan pada proses dan hasil belajar ke arah pencapaian kompetensi tertentu.

Sains merupakan suatu kesatuan produk, proses, dan sikap, sehingga tujuan pembelajaran IPA pada aspek kimia harus pula mengacu pada ketiga aspek esensial tersebut, yaitu: (1) pengetahuan, berupa pemahaman konsep, hukum, dan teori serta penerapannya; (2) kemampuan melakukan proses, yaitu proses pemecahan masalah melalui metode ilmiah yang meliputi penyusunan hipotesis, perancangan eksperimen atau percobaan, evaluasi, pengukuran, dan penarikan kesimpulan; (3) sikap keilmuan, antara lain berupa kecenderungan keilmuan, berpikir kritis, berpikir analitis, tanggung jawab, perhatian pada masalah-masalah sains, dan penghargaan pada hal-hal yang bersifat sains (Toharuddin, dkk, 2011: 28). Karena itu, pembelajaran IPA pada aspek kimia seyogyanya dilakukan dengan pendekatan yang tepat, yaitu memadukan antara pengalaman proses sains dengan pemahaman produk sains dalam bentuk pengalaman langsung, baik berupa kegiatan laboratorium maupun kegiatan lapangan.

Pada tingkat SMP/MTs, pembelajaran IPA ditekankan pada pemberian pengalaman belajar secara langsung melalui penggunaan dan pengembangan keterampilan proses sains dan sikap ilmiah. Oleh 
karena itu pembelajaran IPA sebaiknya dilaksanakan secara inkuiri ilmiah (scientific inquiry) untuk menumbuhkan kemampuan berpikir, bekerja dan bersikap ilmiah serta mengkomunikasikannya sebagai aspek penting kecakapan hidup (Depdiknas, 2006).

Pentingnya keterampilan proses ini dikembangkan menurut Ibrahim, dkk (2010), karena dengan keterampilan proses itu seseorang akan mampu belajar mandiri, mengembangkan diri sendiri, dan belajar sepanjang hayat. Keterampilan proses sains merupakan keterampilan yang diperlukan dalam melakukan penelitian dan pemecahan masalah. Kemampuan pemecahan masalah ini merupakan salah satu kecakapan hidup (life skills) yang perlu dimiliki siswa sebagai bekal dalam meneruskan kehidupannya. Oleh karena itu, pembelajaran IPA pada aspek kimia perlu membekali siswa dengan keterampilan proses sains.

Observasi terhadap perencanaan pembelajaran dan wawancara langsung dengan guru-guru IPA di SMP Negeri 3 Sugio Lamongan menunjukkan bahwa keterampilan proses sains sebagai salah satu aspek penting yang perlu dilatihkan kepada siswa dalam pembelajaran IPA, kurang mendapat perhatian guru. Hal ini dibuktikan dengan beberapa fakta sebagai berikut: (1) RPP yang dikembangkan guru belum sepenuhnya menerapkan model pembelajaran inovatif, khususnya model pembelajaran yang menempatkan siswa sebagai pusat pembelajaran (student centered instruction), (2) dalam mengembangkan RPP, belum terlihat adanya upaya yang terencana untuk mengembangkan keterampilan proses sains siswa melalui perancangan dan pelaksanaan kegiatan eksperimen, (3) pembelajaran IPA yang dilakukan selama ini kurang memberikan kesempatan kepada siswa untuk mengembangkan keterampilan proses sains melalui aktivitas eksperimen atau percobaan di laboratorium, (4) guru-guru jarang melatihkan keterampilan proses sains kepada siswa, hal ini disebabkan karena kurangnya pemahaman guru bagaimana mengembangkan LKS untuk melatihkan keterampilan proses sains kepada siswa, (5) guru tidak mengetahui adanya alternatif lain, misalnya program aplikasi simulasi $\mathrm{PhET}$, yang dapat digunakan untuk melakukan eksperimen atau percobaan melalui laboratorium virtual, dan (6) evaluasi hasil belajar yang dilakukan guru lebih menekankan pada aspek produk, tetapi kurang memberikan perhatian pada aspek proses dan kinerja siswa.

Pembelajaran IPA pada aspek kimia, khususnya materi asam, basa, dan garam di SMP Negeri 3 Sugio Lamongan selama ini dilaksanakan hanya pada identifikasi asam basa menggunakan indikator alami karena bahannya mudah didapatkan di lingkungan sekitar siswa, sedangkan pembelajaran inkuiri untuk melatihkan keterampilan proses sains tidak dilaksanakan dengan alasan guru tidak mengetahui cara mengembangkan RPP dan LKS inkuiri yang dapat melatihkan keterampilan proses sains kepada siswa, sehingga dapat dipahami bahwa dengan pembelajaran semacam itu, keterampilan proses sains tidak dilatihkan dengan baik pada materi asam, basa, dan garam.
Demikian pula bahwa pembelajaran alternatif menggunakan media berupa program simulasi PhET untuk melatihkan keterampilan sains tidak dilakukan guru, karena guru belum mengetahui adanya alternatif pembelajaran tersebut, yang dapat diterapkan untuk mengatasi berbagai kesulitan.

Menurut Nur (1998) pembelajaran keterampilan proses adalah proses belajar mnegajar yang dirancang sedemikian rupa sehingga siswa dapat menemukan fakta-fakta, membangun konsep-konsep, dan teori-teori dengan keterampilan proses ilmiah siswa sendiri. Pendekatan pembelajaran keterampilan proses dapat berjalan jika siswa telah memiliki keterampilan proses yang diperlukan dalam pembelajaran. Hal ini berarti bahwa agar siswa memiliki keterampilan proses sebagai hasil dari pembelajaran, maka keterampilan proses tersebut perlu dilatihkan kepada siswa.

Rusmiyati dan Yulianto (2009) menyatakan bahwa kegiatan penyelidikan dan percobaan dapat melatih siswa untuk memperoleh keterampilan proses sains. Menurut Collete dan Chiapetta (1994), keterampilan proses sains adalah kemampuan dalam melaksanakan tahap-tahap percobaan, yang merupakan keterampilan proses terpadu meliputi keterampilan merumuskan masalah, menyusun hipotesis, menentukan variabel percobaan, merancang percobaan, mengumpulkan data, menganalisis data, dan merumuskan kesimpulan. Hal ini kemudian diperkuat oleh Gulo (2002) yang menyatakan bahwa keterampilan inkuiri merupakan suatu proses yang bermula dari merumuskan masalah, merumuskan hipotesis, mengumpulkan data, menganalisis data, dan membuat kesimpulan. Dengan demikian, untuk melatihkan keterampilan proses sains, dapat digunakan model pembelajaran inkuiri, dimana StaverdanBay (dalam Vajoczki, dkk 2011) dan Bell, dkk (2005) membedakan tigajenisinkuiri menurut tujuannya, yaitu: inkuiriterstruktur (Structured Inquiry), inkuiri terbimbing (Guided Inquiry)dan inkuiri terbuka (Open Inquiry). Pavelich dan Abraham (1979) membagi pembelajaran inkuiri menjadi 2 (dua) bentuk, yaitu Kelas Bebas (free inquiry) dan inkuiri terbimbing (guided inquiry). Dalam Inkuiri Terbimbing(GI) sebagai model inkuiri yang dipilih dan digunakan dalam penelitian ini, gurumemberikanmateridan isu-isu, yang berfungsi sebagaisaranainvestigasi, tetapipeserta didikmerancangprosedurmereka sendiri untukmemecahkan masalah. GIdigunakanuntuk menantangpemahaman konseptualsiswa danketerampilan, mengembangkan kreativitas, untuk menemukanpemahaman yang lebih dalamdanlebih luasdarimateri pembelajaran, dan untuk memperolehbeberapaketerampilan penelitian.

Suchman (dalam Collete dan Chiapetta, 1994) menyatakan bahwa pembelajaran inkuiri merupakan suatu pendekatan yang menempatkan siswa pada posisi find out dan explain how, dan pembelajaran berpusat pada siswa. Sementara Gulo (2002) mendefinisikan strategi inkuiri sebagai suatu rangkaian kegiatan belajar yang melibatkan secara maksimal seluruh kemampuan siswa untuk mencari dan menyelidiki secara sistematis, kritis, logis, dan analitis sehingga mereka dapat 
merumuskan sendiri penemuannya dengan percaya diri. Dengan demikian, sasaran utama pembelajaran Kelas Adalah: (1) keterlibatan siswa secara maksimal dalam proses kegiatan belajar, (2) keterarahan kegiatan secara logis dan sistematis pada tujuan pembelajaran, dan (3) mengembangkan sikap percaya diri siswa tentang apa yang ditemukan dalam proses inkuiri. Sejalan dengan hal ini, Rustaman (2011) menyatakan bahwa pembelajaran berbasis inkuiri memberi peluang kepada peserta didik untuk terus mengembangkan potensi diri secara optimal, baik dari sisi kognitif, afektif, maupun psikomotor. Melalui inkuiri, konsep-konsep sains ditemukan sendiri oleh peserta didik, peserta didik juga dilatih untuk mengembangkan keterampilan proses sains, membekali peserta didik dengan kemampuankemampuan seperti yang dimiliki para ilmuwan sehingga memiliki kemampuan untuk memecahkan masalah yang dihadapi.

Keterampilan-keterampilan ini akan dapat dicapai apabila siswa mengalami sendiri kegiatan percobaan atau eksperimen dalam laboratorium riil dengan menggunakan alat dan bahan praktikum yang sebenarnya. Namun seringkali kegiatan praktikum dalam laboratorium riil semacam itu tidak dapat terlaksana, baik karena tidak tersedianya ruang lab, maupun karena keterbatasan alat dan bahan praktikum. Dalam kondisi seperti ini, guru dituntut memiliki alternatif pembelajaran agar tetap dapat melatihkan keterampilan proses sains melalui kegiatan eksperimen. Keterbatasan pembelajaran dengan eksperimen dalam laboratorium juga dapat disimulasikan dengan menggunakan program multimedia komputer, misalnya berupa program simulasi.Wellington (2004) menyatakan bahwa multimedia memiliki keunggulanyang cukup besar dibandingkan dengan sumber dayalainnya (misalnya, buku dan bahan cetak lainnya) dalam pembelajaran, terutama bahwa multimedia dapat memberikan banyak kemungkinan untukkerja praktek atau aktivitas lapangan dimana sumber dayalain tidak bisa melakukannya, misalnya: eksperimen virtual, simulasi, situasi kehidupan nyatauntuk belajar, dan demonstrasi. Menurut Thoman dan Jolls (2004), meskipun multimedia sebagai alat tidak dapat menggantikan pembelajaran dengan tangan (hand-on learning), tetapi dapat meningkatkandan memperkuat dampak dari kegiatan di lapangan dandi kelas sains. Taylor, dkk (1994) menyatakan bahwa ada manfaat nyata yang dapat diperoleh dari pemanfaatan multimedia. Beberapa di antaranya berasal dari cara memberikan pengalamanyang dilakukan. Dengan demikian, penggunaan multimedia dalam pembelajaran juga dapat digunakan untuk melatihkan keterampilan proses sains. Simulasi PhET misalnya, dirancang sedemikian rupa sehingga siswa seolah-olah merangkai dan menggunakan alat yang sebenarnya dalam laboratorium. Dengan sifatnya yang demikian, simulasi $\mathrm{PhET}$ dapat difungsikan sebagai laboratorium virtual. Menurut Eggen dan Kauchak (2012), meskipun simulasi tidak memberikan pengalaman langsung bagi siswa, tetapi simulasi lebih fleksibel dan interaktif sehingga dapat meningkatkan motivasi dan pemahaman siswa.
Berbagai penelitian menunjukkan bahwa pembelajaran inkuiri yang dipadukan dengan pemanfaatan teknologi informasi dan komunikasi memberikan hasil yang cukup baik. Liliasari (2010) mengungkapkan bahwa pembelajaran inkuiri menggunakan laboratorium berbasis teknologi informasi dan komunikasi disukai siswa karena dapat mengaktifkan siswa, mendukung teori dan praktikum di laboratorium, membangkitkan motivasi siswa, meningkatkan pengetahuan konsep, serta melatih siswa berpikir kreatif karena harus memahami teks, tabel, atau grafik. Senada dengan hal tersebut, Baser (2010) melaporkan bahwa pembelajaran Kelas Berbasis virtual laboratory lebih efektif daripada menggunakan real laboratory, karena dapat meningkatkan pemahaman siswa terhadap konsep abstrak pada materi listrik dinamis, serta dapat meningkatkan keterampilan proses sains siswa. Dalam penelitian yang lain, Darmawati (2012) menyimpulkan bahwa (1) hasil belajar siswa setelah diberikan pembelajaran model Kelas Berbasis program simulasi PhET lebih baik daripada pembelajaran Kelas Berbasis KIT Listrik Dinamis, (2) tidak ada perbedaan keterampilan proses sains siswa setelah diberikan pembelajaran model Kelas Berbasis program simulasi $\mathrm{PhET}$ dan pembelajaran Kelas Berbasis KIT Listrik Dinamis.

\section{METODE PENELITIAN}

$\begin{array}{ccr}\begin{array}{c}\text { Penelitian } \\ \text { pengembangan }\end{array} & \text { ini termasuk } & \text { penelitian } \\ \text { (developmentresearch) } & \text { karena }\end{array}$ mengembangkan perangkat pembelajaran inkuiri berbantuan programSimulasi PhET pada materi pokok Asam, Basa, dan Garam SMP kelas VII. Perangkat pembelajaran yang dikembangkan adalah RPP, BAS, LKS, Tes Pemahaman Konsep, dan Tes Keterampilan Proses. Penelitian dilaksanakan pada siswa kelas VII SMP Negeri 3 Sugio Lamongan sebanyak 86 orang, untuk materi asam, basa, dan garam pada semester ganjil tahun pelajaran 2013/2014.

Pengembangan perangkat dalam penelitian ini menggunakan model 4-D (Thiagarajan, 1974), yaitu: (1) tahap pendefinisian atau define, (2) tahap perancangan perangkat atau design, dan (3) tahap pengembangan perangkat atau develop, tanpa tahap keempat yaitu pendiseminasian (disseminate).

Desain ujicoba perangkat pembelajaran dalam pengembangan perangkat ini menggunakan model pre eksperimen One Group Pretest-Posttest Design. Sebelum melaksanakan pembelajaran dilaksanakan tes awal (pretest, $\mathrm{U}_{1}$ ), dan setelah melaksanakan pembelajaran inkuiri berbantuan program simulasi $\operatorname{PhET}(\mathrm{X})$ dilakukan tes akhir (posttest, $\mathrm{U}_{2}$ ).

Variabel atau karakteristik yang diamati dalam penelitian adalah (1) kelayakan perangkat pembelajaran, meliputi: validitas RPP, BAS, LKS, Tes Pemahaman Konsep dan Tes Keterampilan Proses; dan keterbacaan BAS dan LKS, (2) keterlaksanaan RPP, (3) efektifitas perangkat pembelajaran, yaitu: hasil belajar pemahaman konsep dan keterampilan proses, aktivitas siswa, dan respons siswa, dan (4) hambatan-hambatan selama kegiatan belajar mengajar. 
Instrumen yang digunakan dalam penelitian ini adalah instrumen validitas perangkat, instrumen pengamatan, instrumen tes, dan instrumenangket. Data yang dianalisis adalah kelayakan perangkat, keterlaksanaanpembelajaran, dan keefektifitas perangkat dengan menggunakan teknik analisis deskriptif kualitatif dan statistik inferensial

\section{HASIL DAN PEMBAHASAN}

\section{Hasil Pengembangan Perangkat}

Perangkat yang dikembangkan dalam penelitian ini meliputi:(1) Rencana Pelaksanaan Pembelajaran, (2) Buku Ajar Siswa, (3) Lembar Kegiatan Siswa, (4) Tes Pemahaman Konsep, dan (5) Tes Keterampilan proses sains.

RPP yang dikembangkan mengacu pada PP nomor 19 tahun 2005 tentang standar proses, bab IV pasal 20 bahwa perencanaan proses pembelajaran meliputi silabus dan rencana pelaksanaan pembelajaran yang memuat sekurang-kurangnya tujuan pembelajaran, materi ajar, metode pengajaran, sumber belajar, dan penilaian hasil belajar (Depdiknas, 2005) dan mengadaptasi fase-fase kegiatan pembelajaran inkuiri terbimbing untuk membuka ruang yang lebih luas bagi keterlibatan siswa secara aktif dalam kegiatan penyelidikan (inquiry) sehingga siswa dapat menemukan sendiri pengetahuannya melalui interaksi siswa dalam pembelajaran, baik interaksi dengan guru, interaksi dengan sesama siswa, interaksi dengan media pembelajaran, maupun interaksi dengan berbagai sumber belajar. Adaptasi sintaks-sintaks pembelajaran inkuiri terbimbing ke dalam RPP secara simultan juga dimaksudkan untuk melatihkan keterampilan proses sains, yaitu keterampilan-keterampilan yang dipelajari siswa pada saat mereka melakukan inkuiri ilmiah (Nur, 2003).Hal ini mengacu kepada pernyataan Dewey (dalam Arends, 2007) bahwa guru perlu menciptakan lingkungan belajar yang ditandai oleh prosedurprosedur yang demokratis dan proses-proses ilmiah dimana tanggung jawab utama guru adalah melibatkan siswa dalam penyelidikan (inquiry). Hasil validasi menunjukkan bahwa keseluruhan RPP yang dikembangkan oleh peneliti memiliki kategori validasi baik dengan rata-rata skor sebesar 3,49, sehingga dapat digunakan dengan sedikit revisi dan reliabilitas perangkat sebesar $82,6 \%$ atau reliabel.

Buku Ajar Siswa (BAS) yang dikembangkan peneliti memiliki kategori baik dengan skor validasi ratarata 3,44, sehingga dapat digunakan dengan sedikit revisi atau perbaikan, dengan reliabilitas sebesar 79,2\% menunjukkan bahwa BAS adalah reliabel.Buku Ajar Siswa (BAS) untuk konsep asam, basa, dan garam ini dikembangkan berdasarkan pendekatan komunikatif, dilakukan dengan memperhatikan bekal awal dan karakteristik siswa (Richterich dalam Sodiq, 2009) dan mempertimbangkan bahwa interaksi siswa dengan sumber belajar (buku ajar siswa) merupakan hal yang penting dalam mengkonstruksi pengetahuan baru, namun penyajian informasi dalam buku siswa hendaknya bukanlah dalam bentuk pengetahuan jadi (ready made). Implikasi penting teori Piaget dalam pembelajaran adalah bahwa penyajian pengetahuan jadi (ready made) tidak mendapat penekanan, sebaliknya anak didorong untuk menemukan sendiri pengetahuan itu (discovery atau inquiry) melalui interaksi spontan dengan lingkungannya. Sebab itu, guru dituntut untuk mempersiapkan berbagai kegiatan yang memungkinkan anak melakukan kegiatan secara langsung dengan dunia fisik. Piaget (dalm Slavin, 1994) menyatakan bahwa perkembangan kognitif sebagian besar bergantung kepada seberapa jauh anak aktif memanipulasi dan aktif berinteraksi dengan lingkungannya. Sehingga, dengan meningkatnya aktivitas siswa dalam berinteraksi dengan sumber belajar (buku ajar siswa) akan terjadi perubahan pada diri siswa dalam bentuk penguasaan pengetahuan baru, dimana siswa mengkonstruksi pengetahuannya dengan menghubungkan pengetahuan baru yang diperolehnya dari sumber belajar (buku ajar siswa) dengan pengetahuan yang disimpan dan telah diperoleh sebelumnya.

LKS yang dikembangkan memiliki kategori validasi sangat baik, dengan skor rata-rata 3,63 sehingga dapat digunakan tanpa revisi dan memiliki reliabilitas yang baik, yaitu sebesar 75,0\%.LKS yang dikembangkan bertujuan melatihkan keterampilan proses sains terpadu (integrated science process skills), yaitu kecakapan ilmiah untuk menemukan konsep atau prinsip IPA. Collete dan Chiapetta (1994) menyatakan bahwa keterampilan proses sains merupakan kemampuan dalam melaksanakan tahap-tahap percobaan, yang merupakan keterampilan proses terpadu, meliputi kemampuan-kemampuan merumuskan masalah, menyusun hipotesis, menentukan variabel percobaan, merancang percobaan, mengumpulkan data, menganalisis data, dan merumuskan kesimpulan. Oleh karena itu maka LKS inkuiri yang dikembangkan memuat tahap-tahap kegiatan untuk melatihkan keterampilan proses sains tersebut. Menurut Vygotsky, bahwa perkembangan seseorang dapat dibedakan menjadi dua tingkat, yaitu tingkat perkembangan aktual dan tingkat perkembangan potensial (Arends, 2007). Tingkat perkembangan aktual tampak dari kemampuan seseorang untuk menyelesaikan tugas-tugas dan berbagai masalah secara mandiri, sedangkan tingkat perkembangan potensial tampak dari kemampuan seseorang untuk menyelesaikan tugas-tugas dan memecahkan masalah ketika dibimbing orang dewasa atau ketika berkolaborasi dengan teman sebaya yang lebih kompeten. Dengan demikian, belajar dapat berlangsung melalui interaksi dengan guru atau teman sebaya yang lebih mampu. Dalam kaitan dengan hal tersebut, maka untuk tahap awal pembelajaran inkuiri, dikembangkan LKS Pra Eksperimen sebagai bentuk scaffolding atau bimbingan guru kepada siswa untuk memahami kecakapan-kecakapan ilmiah atau keterampilan proses yang akan dilatihkan. Bimbingan secara terbatas dan berjenjang pada tahap selanjutnya dilakukan melalui kegiatan penyelidikan dalam LKS Eksperimen (LKS 1 s.d. LKS 4) yang dilaksanakan dalam kelompok-kelompok kecil siswa. Hal ini dimaksudkan agar siswa lebih aktif dalam berinteraksi 
dan berkolaborasi dengan siswa lainnya, sehingga dapat mencapai hasil belajar yang lebih maksimal.

Tes pemahaman konsep yang dikembangkan memiliki validitas yang baik, dimana 10 (sepuluh) butir soal dinyatakan valid sehingga dapat digunakan tanpa revisi, sedangkan 10 (sepuluh) butir soal lainnya dinyatakan valid tetapi perlu adanya revisi. Ditinjau dari aspek reliabilitasnya, instrumen tes pemahaman konsep yang dikembangkan telah memiliki reliabilitas yang baik karena memiliki Percentage of Agreement sebesar $80,0 \%$. Tes ini dikembangkan untuk mengukur pencapaian hasil belajar siswa pada aspek pemahaman konsep. Dalam versi revisi taksonomi Bloom (Krathwohl, 2002), pemahaman merupakan hasil belajar siswa pada ranah kognitif yang dicirikan oleh kemampuan-kemampuan menafsirkan (interpreting), memberi contoh (examplifying), mengklasifikasi (classifying), meringkas (summarizing), menarik inferensi (inferring), membandingkan (comparing), dan menjelaskan (explaining). Menurut Ibrahim (2005), seseorang dapat dikatakan memahami bila dia mampu membangun pengertian dari pesan pembelajaran dalam bentuk, komunikasi lisan, tertulis maupun gambar. Menurut Rustaman (2010), pemahaman didefinisikan sebagai kemampuan untuk menyerap arti dari materi atau bahan yang dipelajari. Pemahaman merupakan hasil proses belajar mengajar yang menunjukkan bahwa individu dapat menjelaskan atau mendefinisikan suatu unit informasi dengan kata-kata sendiri. Siswa tidak hanya mengingat kembali pelajaran, namun siswa telah memahami materi pelajaran meskipun dalam bentuk kalimat yang berbeda, tetapi kandungan maksudnya tidak berubah.

Tes keterampilan proses merupakan alat evaluasi yang dikembangkan untuk mengukur pencapaian hasil belajar siswa berupa keterampilan proses sains. Keterampilan proses sains adalah keterampilanketerampilan yang dipelajari siswa pada saat mereka melakukan inkuiri ilmiah (Nur, 2003), mereka menggunakan berbagai macam keterampilan proses, bukan hanya satu metode ilmiah tunggal. Keterampilanketerampilan proses tersebut adalah perumusan hipotesis, pengontrolan variabel, melakukan eksperimen, pengklasifikasian, penginferensian, peramalan, pengkomunikasian, pengukuran, penggunaan bilangan, penginterpretasian data, pendefinisian secara operasional, dan perumusan model (Nur, 2003). Instrumen tes ini dikembangkan dalam bentuk soal uraian berdasarkan indikator atau tujuan hasil belajar yang telah dirumuskan sebelumnya. Tes keterampilan proses yang dikembangkan sebanyak 7 (tujuh) butir soal uraian memiliki validitas yang sangat baik, karena ketujuh butir soal tersebut dinyatakan valid sehingga dapat digunakan tanpa revisi. Ditinjau dari aspek reliabilitasnya, instrumen tes keterampilan proses juga telah memenuhi syarat karena memiliki reliabilitas (Percentage of Agreement) sebesar 100\%.

\section{Hasil Implementasi Perangkat Pembelajaran}

\section{(1) Keterlaksanaan Pembelajaran}

Keterlaksanaan RPP berada pada kriteria sangat baik. Sebagaimana disajikan pada Gambar1, persentase rata-rata keterlaksanaan pembelajaran inkuiri pada masing-masing kelas implementasi adalah sebesar 97,5\% (Kelas A), 95,5\% (Kelas B), dan 96,5\% (Kelas C). Sesuai dengan kriteria yang ditetapkan, maka tingkat keterlaksanaan RPP secara keseluruhan berada pada kriteria sangat baik, karena persentase keterlaksanaannya $\geq 81 \%$ (Borich, 1994).

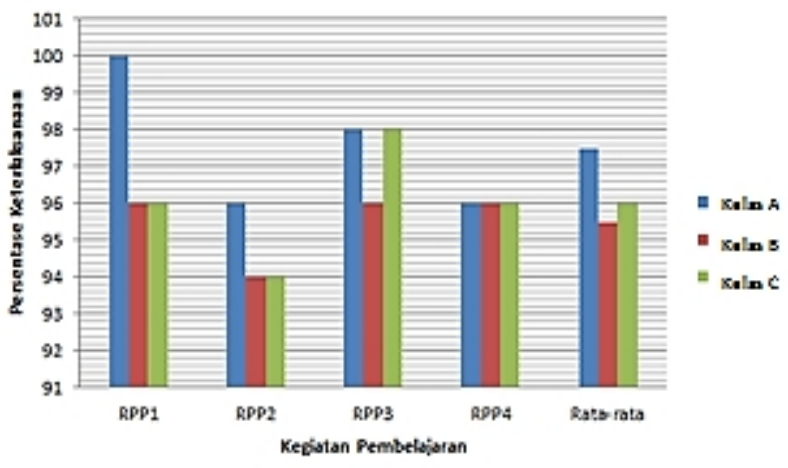

Gambar 1

Grafik Keterlaksanaan RPP

Keterlaksanaan pembelajaran yang sangat baik ini dapat dicapai karena beberapa hal, yaitu: (1) adanya perencanaan yang baik mulai dari perencanaan materi, pengelolaan kelas, sumber belajar, hingga dukungan media pembelajaran yang akan digunakan, (2) ketersediaan perangkat pembelajaran (buku ajar, LKS, dan instrumen penilaian), alat dan bahan praktikum, serta perangkat TIK dengan kuantitas dan kualitas yang memadai, (3) bimbingan terbatas yang diberikan guru (scaffolding) dalam bentuk kegiatan pra eksperimen memudahkan siswa dalam memahami jenis-jenis keterampilan proses yang akan dilatihkan, dan (4) peran guru dalam pembelajaran berupa penguasaan terhadap materi pembelajaran maupun pengelolaan kelas, termasuk dalam mengimplementasikan sintaks-sintaks pembelajaran inkuiri.Penguasaan guru ini ditunjang pula dengan komitmen yang tinggi untuk melaksanakan pembelajaran sesuai dengan perangkat pembelajaran yang telah dikembangkan, sehingga dapat menciptakan suasana pembelajaran yang mendukung aktivitas siswa untuk menemukan dan mengkonstruksi pengetahuannya melalui kegiatan penyelidikan. Hal ini sejalan dengan apa yang dinyatakan oleh Collete dan Chiapetta (1994) bahwa pendekatan pembelajaran inkuiri membutuhkan guru yang dapat menumbuhkan lingkungan belajar yang dapat merangsang rasa ingin tahu siswa untuk melakukan penyelidikan.

\section{(2) Keterbacaan Buku Ajar Siswa dan LKS}

Hasil analisis keterbacaan Buku Ajar Siswa dan LKS pada Gambar 2 menunjukkan bahwa untuk Buku Ajar Siswa tingkat keterbacaannya mencapai 89,15\% dan untuk LKS tingkat keterbacaannya mencapai $86,00 \%$, dengan kategori mudah karena persentase keterbacaannya $\geq 61 \%$ (Ridwan, 2012). 


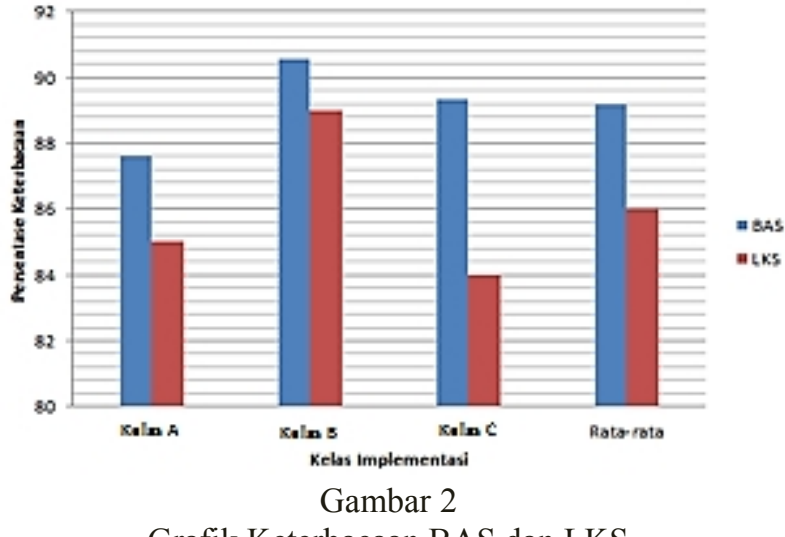

Grafik Keterbacaan BAS dan LKS

Keterbacaan Buku Ajar Siswa dengan persentase $89,15 \%$ diperoleh dari rata-rata persentase keterbacaan pada masing-masing kelas implementasi, yaitu 87,59\% pada Kelas A, 90,54\% pada Kelas B, dan 89,31\% pada Kelas C. Demikian pula dengan keterbacaan LKS sebesar $86,00 \%$ diperoleh dari rata-rata persentase keterbacaan pada masing-masing kelas implementasi, yaitu $85,00 \%$ pada Kelas A, 89,00\% pada Kelas B, dan $84,00 \%$ pada Kelas C. Keterbacaan semacam ini menunjukkkan bahwa buku ajar siswa dan LKS yang dikembangkan peneliti mudah dipahami isinya oleh pembaca (siswa). Kemudahan memahami buku ajar dan LKS tersebut dapat memotivasi siswa untuk lebih tertarik membaca buku siswa tersebut, sehingga dengan tingkat keterbacaan yang tinggi akan menunjang tercapainya mutu pendidikan (Suryadi, 2007). Dengan membaca buku ajar siswa dan LKS tersebut berarti telah terjadi interaksi siswa dengan sumber belajar, dimana siswa dapat menggali dan menemukan informasi atau pengetahuannya dari materi buku ajar dan LKS yang dibacanya. Dalam perspektif kognitifkonstruktivis, Piaget (dalam Slavin, 1994) menyatakan bahwa pelajar dengan umur berapapun terlibat secara aktif dalam proses mendapatkan informasi dan mengkonstruksi pengetahuannya sendiri, dimana perkembangan kognitif sebagian besar bergantung kepada seberapa jauh anak aktif memanipulasi dan aktif berinteraksi dengan lingkungannya. Tersedianya buku ajar dan LKS dengan tingkat keterbacaan yang tinggi berarti membuka ruang yang lebih luas bagi siswa untuk berinteraksi dengan lingkungan belajarnya dan membantu siswa untuk mengkomunikasikan pengetahuan baru yang diperoleh dari membaca buku ajar siswa dengan pengetahuan yang sudah dimiliki sebelumnya. Bruner dalam hal ini mengemukakan dua asumsi tentang siswa belajar, bahwa (1) perolehan pengetahuan merupakan suatu proses interaktif dengan lingkungannya, dimana Bruner meyakini bahwa orang yang belajar berinteraksi dengan lingkungannya secara aktif, perubahan tidak hanya terjadi di lingkungan, tetapi juga dalam diri orang itu, dan (2) orang mengkonstruksi pengetahuannya dengan menghubungkan informasi yang masuk dengan informasi yang disimpan dan diperoleh sebelumnya.

\section{(3) Pemahaman Konsep Siswa}

Pengukuran pemahaman konsep siswa dengan menggunakan instrumen tes pemahaman konsep pada ketiga kelas implementasi sebelum dan sesudah dilakukannya pembelajaran inkuiri berbantuan program simulasi PhET menunjukkan hasil sebagai berikut:

a. Perolehan nilai rata-rata siswa pada setiap kelas implementasi sebesar 83,10 (Kelas A), 81,25 (Kelas B), dan 83,45 (Kelas C). Perolehan ini meningkat secara signifikan jika dibandingkan dengan perolehan sebelum pembelajaran (Gambar 3).

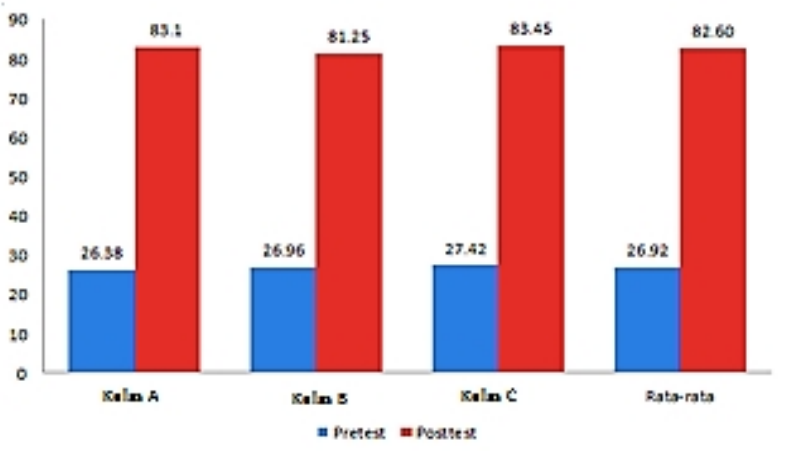

Gambar 3

Grafik Ketuntasan Individual

Hasil Belajar Pemahaman Konsep

b. Ketuntasan klasikal terlampaui, karena $93,10 \%$ siswa tuntas pada Kelas A, 92,86\% pada Kelas B, dan $89,66 \%$ pada Kelas C , masing-masing > $85 \%$.Ketuntasan ini meningkat secara signifikan jika dibandingkan dengan sebelum dilakukannya pembelajaran (Gambar 4)

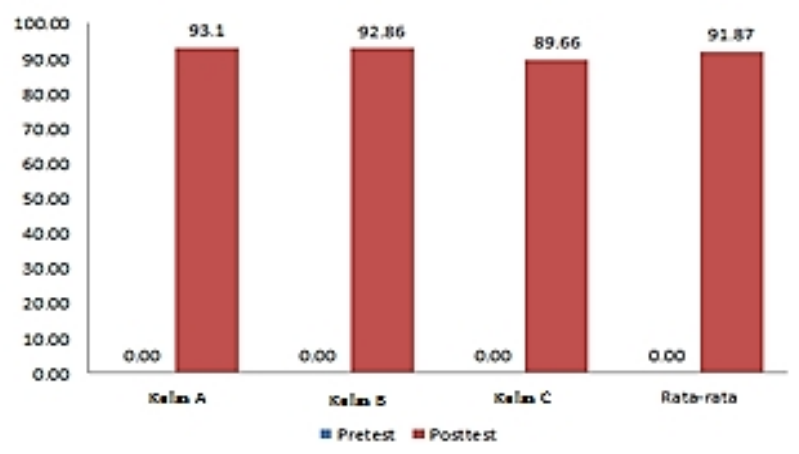

Gambar 4

Grafik Ketuntasan Klasikal

Hasil Belajar Pemahaman Konsep

(3) $100 \%$ indikator mencapai ketuntasan dengan persentase ketercapaian indikator pada masing-masing kelas adalah 83,10\% (Kelas A), 81,15\% (Kelas B), dan $83,40 \%$ (Kelas C).Ketuntasan ini meningkat secara signifikan jika dibandingkan dengan sebelum dilakukannya pembelajaran (Gambar 5). 


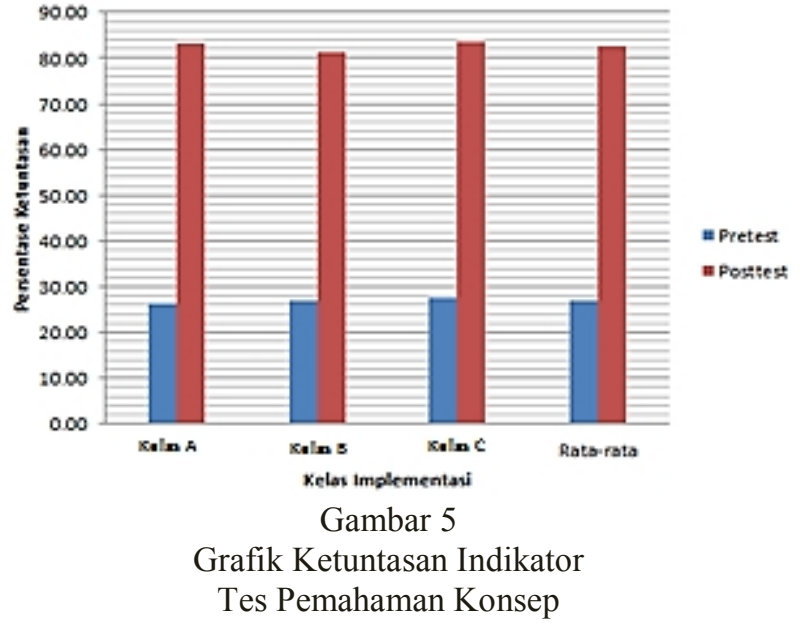

Pencapaian pemahaman konsep yang baik ini merupakan implikasi dari penerapan pembelajaran inkuiri berbantuan program simulasi PhET, yang dibuktikan dengan hasil analisis perbedaan hasil belajar dan sensitivitas soal. Dari hasil uji beda menggunakan dependent $t$-test (paired sample t test) melalui program SPSS pada taraf signifikansi $\alpha=0,05$ diperoleh $P$ value $=0,000$ atau $<0,05$ sehingga terdapat perbedaan yang signifikan antara hasil belajar sebelum dan sesudah dilakukannya pembelajaran inkuiriberbantuan program simulasi PhET. Perbedaan hasil belajar yang signifikan pada masing-masing kelas implementasi ini merupakan efek dari perlakuan yang diberikan kepada siswa berupa pembelajaran yang menerapkan perangkat pembelajaran Kelas Berbantuan paket simulasi PhET, dimana 20 (dua puluh) butir soal yang digunakan mengukur hasil belajar pemahaman konsep siswa memiliki sensitivitas yang baik $(\geq 0,30)$. Dari Gambar 6 diketahui bahwa rata-rata nilai sensitivitas soal yang diperoleh dari ketiga kelas implementasi adalah 0,56.

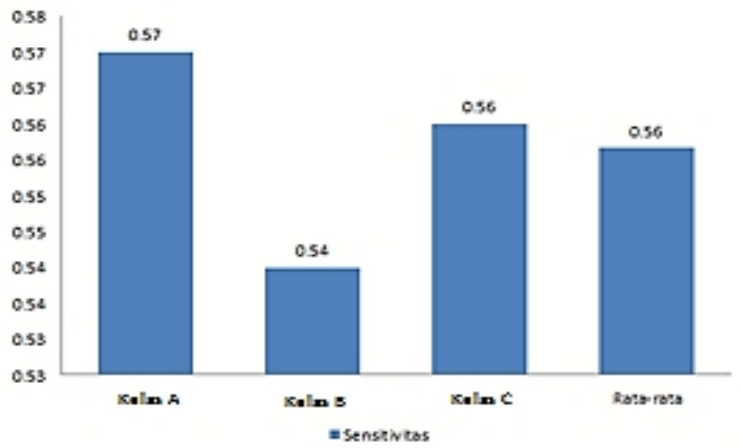

Gambar 6

Grafik Sensitivitas Soal

Tes Pemahaman Konsep

\section{(4) Keterampilan Proses Sains}

Pengukuran hasil belajar keterampilan proses sains siswa dengan menggunakan instrumen tes keterampilan proses sains pada ketiga kelas implementasi sebelum dan sesudah dilakukannya pembelajaran inkuiri berbantuan program simulasi PhET menunjukkan hasil sebagai berikut:

a. Perolehan nilai rata-rata siswa pada setiap kelas implementasi sebesar 82,87 (Kelas A), 82,14 (Kelas B), dan 81,79(Kelas C). Perolehan ini meningkat secara signifikan jika dibandingkan dengan perolehan sebelum pembelajaran (Gambar 7).

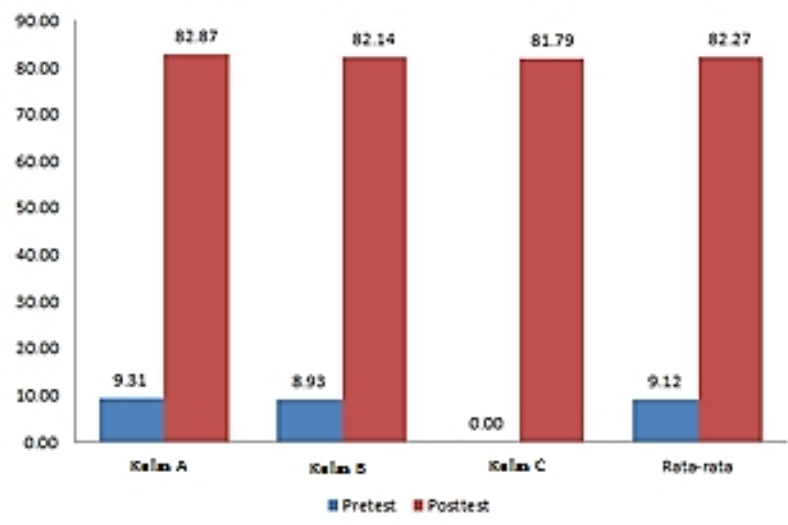

Gambar 7

Grafik Ketuntasan Individual

Hasil Belajar Keterampilan Proses Sains

b. Ketuntasan klasikal terlampaui, karena 86,21\% siswa tuntas pada Kelas A, 89,29\% pada Kelas B, dan $86,21 \%$ pada Kelas C , masing-masing $>85 \%$. Ketuntasan ini meningkat secara signifikan jika dibandingkan dengan sebelum dilakukannya pembelajaran (Gambar 8)

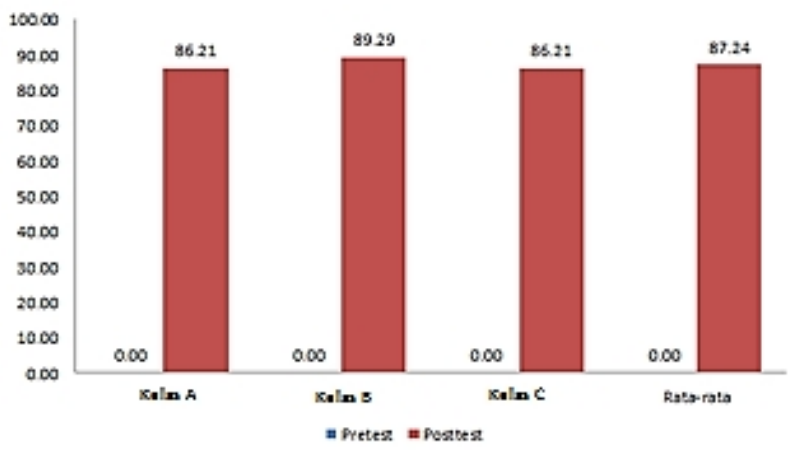

Gambar 8

Grafik Ketuntasan Klasikal

Hasil Belajar Keterampilan Proses Sains

c. $85,71 \%$ indikator mencapai ketuntasan.Terdapat satu indikator yang masih belum mencapai ketuntasan yaitu indikator 4 (merumuskan definisi operasional variabel) karena persentase ketercapaiannya $<75 \%$, yaitu $58 \%$ (Kelas A), $65 \%$ (Kelas B), dan 63\% (Kelas C). Ketuntasan ini meningkat secara signifikan jika dibandingkan dengan sebelum dilakukannya pembelajaran (Gambar 9). 


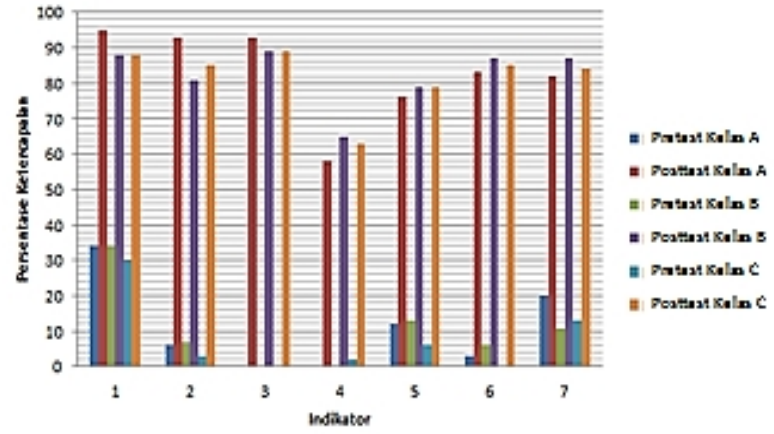

Gambar 9

Grafik Ketuntasan Indikator

Tes Keterampilan Proses Sains

Pencapaian hasil belajar keterampilan proses sains yang baik ini merupakan implikasi dari penerapan pembelajaran inkuiri berbantuan program simulasi PhET, yang dibuktikan dengan hasil analisis perbedaan hasil belajar dan sensitivitas soal. Dari hasil uji beda menggunakan dependent t-test (paired sample $t$ test) melalui program SPSS pada taraf signifikansi $\alpha=0,05$ diperoleh $P$ value $=0,000$ atau $<0,05$ sehingga terdapat perbedaan yang signifikan antara hasil belajar sebelum dan sesudah dilakukannya pembelajaran inkuiri berbantuan program simulasi PhET. Perbedaan hasil belajar yang signifikan pada masing-masing kelas implementasi ini merupakan efek dari perlakuan yang diberikan kepada siswa berupa pembelajaran yang menerapkan perangkat pembelajaran inkuiri berbantuan program simulasi PhET, dimana 7 (tujuh) butir soal yang digunakan mengukur hasil belajar keterampilan proses sains memiliki sensitivitas yang baik $(\geq 0,30)$. Dari Gambar 10 diketahui bahwa rata-rata nilai sensitivitas soal yang diperoleh dari ketiga kelas implementasi adalah 0,73 .

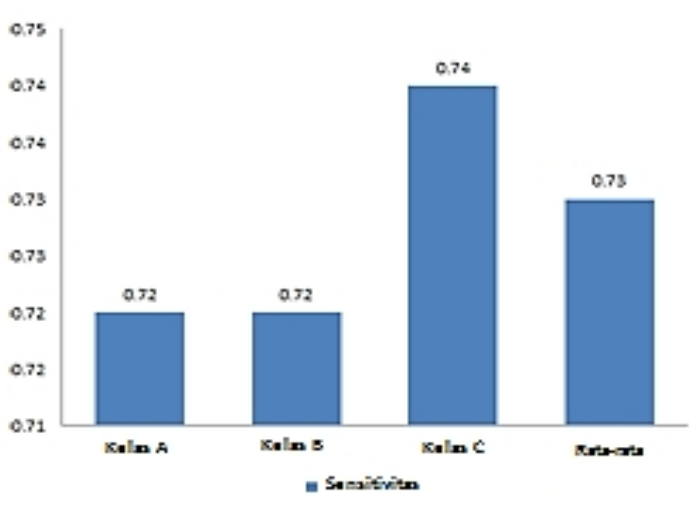

Gambar 10

Grafik Sensitivitas Soal

Tes Keterampilan Proses Sains

\section{(5) Aktivitas Siswa}

Secara umum siswa memiliki keterlibatan yang cukup tinggi dalam kegiatan pembelajaran pada ketiga kelas implementasi yang menggunakan perangkat pembelajaran inkuiri berbantuan program simulasi PhET (Gambar 11). Keterlibatan siswa yang tinggi tersebut misalnya: melibatkan diri dalam kelompok untuk merumuskan hipotesis, mengidentifikasi variabel, dan merumuskan definisi operasional variabel rata-rata sebesar $17,16 \%$, melibatkan diri secara aktif di dalam kelompok untuk mengumpulkan data dengan menggunakan prosedur percobaan yang diberikan guru pada LKS rata-rata sebesar $17,57 \%$, melibatkan diri secara aktif di dalam kelompok untuk menganalisis data rata-rata sebesar $5,70 \%$ dan melibatkan diri secara aktif di dalam kelompok untuk merumuskan kesimpulan percobaan/eksperimen rata-rata sebesar 5,64\%.

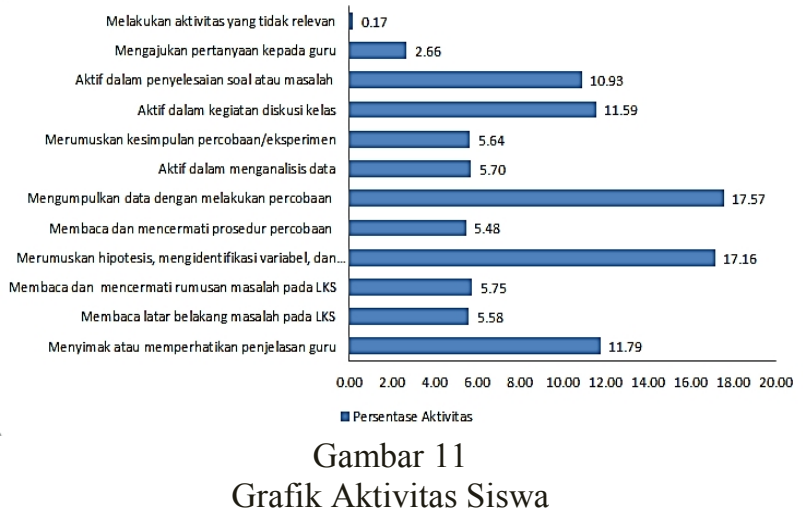

Keterlibatan siswa juga cukup baik pada aktivitas lainnya, misalnya: menyimak dan memperhatikan penjelasan guru rata-rata sebesar $11,79 \%$, melibatkan diri secara aktif dalam kegiatan diskusi kelas rata-rata sebesar 11,59\%, dan melibatkan diri dalam penyelesaian soal atau masalah untuk menerapkan konsep/prinsip/hukum /teori dalam situasi yang lain rata-rata sebesar $10,93 \%$, sedangkan aktivitas yang tidak relevan dengan pembelajaran relative rendah yaitu $0,17 \%$.

\section{(6) Respon Siswa}

Secara keseluruhan, respon siswa terhadap pembelajaran inkuiri berbantuan program simulasi $\mathrm{PhET}$ adalah positip, baik terhadap mataeri atau isi pelajaran, pendekatan pembelajaran inkuiri yang digunakan, keterampilan proses sains yang dilatihkan, perangkat pembelajaran yang digunakan, pengelolaan pembela-jaran, maupun terhadap tes hasil belajar pemahaman konsep dan keterampilan proses yang dilakukan. Rata-rata respon siswa untuk setiap aspek yang ditanyakan pada ketiga kelas implementasi, berkisar 77\% - 100\%, kecuali pada aspek kemudahan dalam mengikuti komponen-komponen keterampilan proses sains yang dilatihkan guru terdapat 39\% siswa pada kelas Kelas A, 39\% siswa pada kelas Kelas B, dan 35\% siswa pada kelas Kelas C memberikan respon bahwa merumuskan definisi operasional variabel merupakan hal yang sulit bagi siswa. Hal ini sejalan dengan hasil temuan Nur (2010) yang menyatakan bahwa siswa SMP dan SMA tampak asing dengan tugas perumusan definisi operasional variabel, bahkan guru sendiri ternyata juga belum menguasai cara merumuskan definisi operasional variabel. Hal ini dapat terjadi karena kemampuan merumuskan definisi operasional variabel adalah keterampilan proses sains 
yang level kognitifnya berada pada level mencipta atau mengkreasi (C6), sehingga jika siswa belum terlatih untuk keterampilan ini, maka sulit baginya untuk dapat melakukannya.

\section{(7) Kendala-kendala Pembelajaran}

Kendala utama yang dihadapi selama dilaksanakannya implementasi terhadap perangkat pembelajaran inkuiri berbantuan program simulasi PhET adalah siswa masih merasa sulit dalam merumuskan definisi operasional variabel sebagaimana diidentifikasi oleh para pengamat. Kendala atau permasalahan tersebut dapat terjadi karena siswa memang belum terbiasa menyelesaikan masalah percobaan/eksperimen dengan keterampilan proses sains. Adanya kendala tersebut menjadi penyebab tidak tercapainya ketuntasan hasil belajar keterampilan proses pada indikator 4, yaitu merumuskan definisi operasional variabel, Menyikapi kendala itu, langkahlangkah yang perlu dilakukan adalah: (1) melatihkan keterampilan proses sains secara berkelanjutan pada setiap pembelajaran IPA oleh semua guru IPA yang ada di sekolah, sehingga dapat membiasakan siswa dengan berbagai jenis keterampilan proses sains yang perlu dikuasai, khususnya dalam merumuskan definisi operasional variabel, (2) mengalokasikan waktu di luar jadwal kegiatan pembelajaran, misalnya melalui kegiatan KIR untuk melatih siswa merancang percobaan dalam rangka melatihkan keterampilan proses, dan (3) menyediakan panduan keterampilan proses yang mudah dipahami oleh siswa, sebagai petunjuk bagi siswa dalam melaksanakan penyelidikan ilmiah dalam pembelajaran IPA.

Hasil-hasil yang diperoleh sebagaimana diuraikan di atas, menunjukkan bahwa perangkat pembelajaran inkuiri berbantuan program simulasi PhET yang dikembangkan dapat diterapkan sebagai solusi dalam mengatasi masalah-masalah pembelajaran yang dihadapi, yaitu untuk: (1) melatihkan keterampilan proses sains kepada siswa yang selama ini jarang dilakukan, (2) memberikan kesempatan yang lebih banyak kepada siswa untuk mengembangkan keterampilan proses sains melalui aktivitas eksperimen atau percobaan di laboratorium, dan (3) sebagai alternatif solusi bagi guru yang dapat digunakan untuk melakukan eksperimen atau percobaan melalui laboratorium virtual menggunakan program simulasi PhET jika terkendala karena keterbatasan peralatan lab. Hal ini dapat dipahami karena simulasi PhET dirancang sedemikian rupa sehingga siswa seolah-olah merangkai dan menggunakan alat yang sebenarnya dalam laboratorium. Dengan sifatnya yang demikian, simulasi PhET dapat difungsikan sebagai laboratorium virtual.

\section{PENUTUP}

\section{Simpulan}

Berdasarkan temuan-temuan dari pelaksanaan implementasi perangkat pembelajaran yang dikembangkan, disimpulkan bahwa perangkat pembelajaran inkuiri berbantuan program simulasi PhET untuk melatihkan keterampilan proses sains dan pemahaman konsep IPA memiliki kelayakan, keterlaksanaan, dan keefektifan yang baik sehingga layak untuk diimplementasikan pada pembelajaran IPA di kelas VII untuk materi asam, basa, dan garam.

\section{Saran-saran}

(1) Pengorganisasian waktu dalam kegiatan pembe-lajaran perlu lebih diefektifkan agar seluruh tahapan kegiatan pembelajaran dapat dilaksanakan secara utuh, (2) Keterampilan proses sains perlu dilatihkan secara berkelanjutan pada setiap pembelajaran IPA oleh semua guru IPA yang ada di sekolah, sehingga dapat membiasakan siswa dengan berbagai jenis keterampilan proses sains yang perlu dikuasai, dan (3) Perlu dialokasikan waktu di luar jadwal kegiatan pembelajaran, misalnya melalui kegiatan KIR untuk memfasilitasi siswa melakukan kegiatan penyelidikan ilmiah dalam rangka melatihkan keterampilan proses, sehingga dapat mengatasi kesulitan yang dialami siswa dalam merumuskan definisi operasional variabel.

\section{DAFTAR PUSTAKA}

Arends, R. I. 2007. Learning To Teach. New York: McGraw Hill Companies, Inc.

Baser, M., Durmus, Soner. 2010. "The Effectiveness of Computer Supported Versus Real Laboratory Inquiry Learning Environtments on The Understanding of Direct Current Electricity among Pre-Service Elementary School Teachers". Eurasia Journal of Mathematics, Science, and Technology Education. Vol. 6 No. 2. pp 47 - 61

Bell, Randi L., Smetana, L., Binns, I. 2005. "Simplifying Inquiry Instruction: Assesing The Inquiry Level of Classroom Activities". The Science Teacher. Vol. 72 No. 7 . pp $30-33$

Borich, G.D. 1994. Observation Skills for Effective Teaching. New York: Macmillan Publishing Company

Collette, A.T. dan Chiapetta, E.L. 1994. Science Instruction in The Middle and Secondary Schools.

New York: Macmillan Publishing Company

Darmawati. 2012. "Model Pembelajaran Kelas Berbasis Paket Program Simulasi PhET untuk Melatihkan Keterampilan Proses Sains Siswa pada Konsep Listrik Dinamis. Tesis Magister Pendidikan, Universitas Negeri Surabaya

Depdiknas. 2006. Peraturan Menteri Pendidikan Nasional Nomor 22 Tahun 2006 tentang Standar Isi untuk Satuan Pendidikan Dasar dan Menengah. Jakarta: Depdiknas

Eggen, Paul D. dan Kauchak, D.P. 2012. Strategies and Models for Teachers: Teaching Content and Thinking Skills, $6^{\text {th }}$ Edition. Boston: Pearson Education Inc

Gulo, W. 2002. Strategi Belajar Mengajar. Jakarta: PT. Grasindo 
Ibrahim, M. 2005. Assesmen Berkelanjutan. Surabaya: Unesa University Press.

Ibrahim, M. 2010. Pengembangan Pembelajaran Berbasis Inkuiri, Modeling, dan Eksperimen. Makalah Seminar Yayasan Beasiswa Tunas Bangsa Surabaya

Krathwohl, D. R. 2002. “A Revision of Bloom's Taxonomy: An Overview". Theory Into Practice. Vol 41 No. 4 Autumn 2002. pp. 212 - 218.

Liliasari, Iriany, dan Setiabudi, A. 2010. Model Pembelajaran Inkuiri Laboratorium Berbasis Teknologi Informasi pada Konsep Laju Reaksi untuk Meningkatkan Keterampilan Generik Sains dan Keterampilan Berpikir Kreatif Siswa SMU. Penelitian Sekolah Pascasarjana UPI, Bandung

Nur, M. 1998. Teori Pembelajaran Kognitif. Surabaya: University Press

Nur, M., Rahayu, Y.S., Wasis, Isna, dan Subekti, H. 2010. Pengembangan Perangkat Pembelajaran untuk Memberi Kemudahan Guru Mengajar dan Siswa Belajar IPA dan Keterampilan Berpikir. Laporan Penelitian Hibah Kompetensi. Surabaya: Unesa.

Nur, M. 2011. Modul Keterampilan-keterampilan Proses Sains. Surabaya: Pusat Sains dan Matematika Sekolah Unesa.

Pavelich, M.J., dan Abraham, M.R. 1979. “An Inquiry Format Laboratory Program for General Chemistry". Journal of Chemical Education. Vol 56. pp $100-103$.

Ridwan, M. 2012. "Keterbacaan wacana dalam buku teks Bahasa dan Sastra Indonesia untuk SMP / MTs kelas VIII Karangan Wahono Terbitan CV Gita Perdana Tahun 2010”. Jurnal Kata (Bahasa, Sastra, dan Pembelajarannya). Vol. 1 No. 2. Hal $14-27$

Rustaman. 2010. Model-model Pembelajaran Mengembangkan Profesionalisme Guru. Jakarta: RajaGrafindo Persada.

Rusmiyati dan Yulianto. 2009. "Peningkatan Keterampilan Proses Sains dengan Menerapkan Model Problem Based Instruction". Jurnal Pendidikan Fisika Indonesia. Vol 7 No. 5. Hal. 75 - 78. http://journal.unnes.ac.id/ nju/index.php/ JPFI/article/view/1013 . diakses 29 Maret 2013.

Slavin, R. E. 1994. Educational Psychology: Theory and Practise. Massachusetts: Allyn and Bacon.

Sodiq, S. 2009. Pengembangan Materi Kecakapan Hidup pada Buku Pelajaran Bahasa Indonesia dengan Model Pembelajaran Literasi. Disertasi Universitas Negeri Surabaya.

Suryadi, A. 2007. "Tingkat Keterbacaan Wacana Sains dengan Teknik Klos". Jurnal Sosioteknologi. Edisi 10 Tahun 6. Hal $196-200$
Taylor, J., Scanlon, E., and Hodgson, B. 1997. "Multimedia and Science Education". Education Research and Perspectives, Special Issue on Multimedia Technologies and Education, Vol. 23, No. pp 48 - 59

Thiagarajan, S. 1974. Instructional Development for Training Center of Exceptional Children. Minepolish: Indiana University.

Thoman, E., dan Jolls, T. 2004. "Media Literacy: A National Priority for a Changing World. American Behavioral Scientist. Vol. 48 No. 1, pp 18 - 29

Toharuddin, U., Hendrawati, S., dan Rustaman, A. 2011. Membangun Literasi Sains Peserta Didik. Bandung: Humaniora

University of Colorado. 2011. PhET Interactive Science Simulations.http://phet.colorado.edu/en/getphet/full-install diunduh 19 Desember 2012

Vajoczki, S., Watt, S., Vine, M.M., dan Liao, X. 2011. "Inquiry Learning: Level, Dicipline, Class Size, What Matter?". International Journal for The Scholarship of Teaching and Learning, Vol. 5 No. 1 , pp $1-11$

Wellington, J. 2004. "Multimedia in Science Teaching”. Barton, R. (Ed). Teaching Secondary Science with ICT. Berkshire, England: Open University Press 